\title{
Workshop Safety and Uncertainty
}

\author{
Thomas Hassel $^{1}$, Volker Mintzlaff ${ }^{2}$, Joachim Stahlmann $^{2}$, Klaus-Jürgen Röhlig ${ }^{3}$, and Anne Eckhardt ${ }^{4}$ \\ ${ }^{1}$ Institut für Werkstoffkunde, Leibniz Universität Hannover, 30823 Garbsen, Germany \\ ${ }^{2}$ Institut für Geomechanik und Geotechnik, Technische Universität Braunschweig, \\ 38106 Braunschweig, Germany \\ ${ }^{3}$ Institut für Endlagerforschung, Technische Universität Clausthal, 38678 Clausthal-Zellerfeld, Germany \\ ${ }^{4}$ risicare GmbH, 8125 Zollikerberg, Switzerland
}

Correspondence: Anne Eckhardt (anne.eckhardt@ risicare.ch)

Published: 10 November 2021

\begin{abstract}
Uncertainties have a significant influence on the assessment and evaluation of the safety of a repository system for high-level radioactive waste. Significant reasons for uncertainties concerning the safety barriers of a repository are:

Conducting experiments on the long-term behaviour of the repository in real time is impossible due to the long assessment period over which the repository is supposed to ensure safety. The extrapolation of results from time-limited experiments, e.g. on the corrosion of container materials, to other temporal dimensions is associated with uncertainties. Uncertainties also stem from differences between experimental situations, e.g. laboratory experiments, and the real conditions in the repository. The interpretation of empirical results can be ambiguous and therefore associated with uncertainties. The development of future impacts on the barriers can only be predicted to a limited extent. Therefore, the future behaviour of the barriers can only be extrapolated into the future to a limited extent on the basis of experience gained in the past and uncertainties remain.

The construction and operation of the repository will disturb its natural environment. The geological environment in which the repository is embedded behaves differently from a natural geological system, which in turn is associated with uncertainties. A major source of uncertainties is also the natural inhomogeneity of the geological barrier, which can only be investigated on a sample basis. During excavation and other construction work underground, unforeseen situations are to be expected, which make it necessary to act situationally. The complexity of the disposal path where decisions are interlinked, creates further uncertainties. Last but not least, it is uncertain what further findings on the safety of the repository will be obtained in the future along the disposal path.

For safety studies, especially studies on the long-term safety of repository systems, methods and conventions for dealing with uncertainties have become established internationally. In the site selection process, these methods and conventions are questioned and, if necessary, must be further developed so that they ultimately also convince the interested public and scientists from other disciplines.

In the workshop, uncertainties will be examined in particular from the perspectives of a civil engineer and of a materials researcher with introductory presentations. This will be followed by a moderated discussion. The workshop will focus on the preliminary safety investigations; however, the discussion can also refer to later phases of the disposal path.

The aim of the discussion is to arrive at a common synthesis: Where have good practices for dealing with uncertainties already been established? Where is there still a need for research and clarification? What needs to be considered in the dialogue with the interested public?
\end{abstract}

Kurzfassung. Ungewissheiten bestimmen die Einschätzung und Beurteilung der Sicherheit eines Endlagersystems wesentlich mit. Wichtige Gründe für Ungewissheiten, welche die Sicherheitsbarrieren eines Endlagers betreffen, sind:

Die Durchführung von Experimenten zum Langzeitverhalten des Endlagers in „Echtzeit“ ist aufgrund des langen Bewertungszeitraums, über den das Endlager Sicherheit gewährleisten soll, unmöglich. Die Extrapolation 
von Ergebnissen aus zeitlich begrenzten Experimenten, z. B. zur Korrosion von Behältermaterialien, auf andere zeitliche Dimensionen ist mit Unsicherheiten verbunden. Ungewissheiten gehen auch auf Unterschiede zwischen experimentellen Situationen, z. B. Laborexperimenten, und den realen Bedingungen im Endlager zurück. Die Interpretation von empirischen Ergebnissen kann mehrdeutig und daher mit Ungewissheiten verbunden sein. Die Entwicklung der künftigen Einwirkungen auf die Barrieren ist nur begrenzt vorhersehbar. Daher lässt sich das künftige Verhalten der Barrieren nur bedingt aufgrund von Erfahrungen, die in der Vergangenheit gemacht wurden, in die Zukunft extrapolieren.

Durch den Bau und Betrieb des Endlagers wird dessen natürliche Umgebung gestört. Das geologische Umfeld, in welches das Endlager eingebettet ist, verhält sich anders als ein natürliches geologisches System, was wiederum mit Ungewissheiten verbunden ist. Eine wesentliche Quelle von Ungewissheiten ist auch die natürliche Inhomogenität der geologischen Barriere, die nur stichprobenartig untersucht werden kann. Beim Erstellen des Grubengebäudes ist mit unvorhergesehenen Situationen, also Ungewissheiten zu rechnen, die es erforderlich machen, situativ zu handeln. Die Komplexität des Entsorgungspfads, auf dem Entscheidungen untereinander vernetzt sind, begründet weitere Ungewissheiten. Nicht zuletzt ist ungewiss, welche weiteren Erkenntnisse zur Sicherheit des Endlagers künftig auf dem Entsorgungspfad gewonnen werden.

Für Sicherheitsuntersuchungen, insbesondere Untersuchungen zur Langzeitsicherheit von Endlagersystemen, haben sich Methoden und Konventionen zum Umgang mit Ungewissheiten international etabliert. Im Standortauswahlverfahren werden diese Methoden und Konventionen hinterfragt und müssen ggf. weiterentwickelt werden, so dass sie schließlich auch die interessierte Öffentlichkeit und Wissenschaftlern anderer Fachdisziplinen überzeugen.

Im Workshop werden Ungewissheiten insbesondere aus der Perspektive eines Bauingenieurs und eines Materialforschers mit Impulsreferaten beleuchtet. Daran schließt sich eine moderierte Diskussion an. Im Zentrum des Workshops stehen die vorläufigen Sicherheitsuntersuchungen. Die Diskussion kann aber auch auf spätere Phasen des Entsorgungspfads verweisen.

Ziel der Diskussion ist es, zu einer gemeinsamen Synthese zu gelangen: Wo haben sich gute Praktiken zum Umgang mit Ungewissheiten bereits etabliert? Wo besteht noch Forschungs- und Klärungsbedarf? Was ist beim Dialog mit der interessierten Öffentlichkeit zu beachten?

Financial support. This research has been supported by the Bundesministerium für Wirtschaft und Energie (grant no. 02E11849A-J) and the Niedersächsische Ministerium für Wissenschaft und Kultur (grant no. 02E11849A-J).

\section{References}

Hassel, T., Mintzlaff, V., Stahlmann, J., Röhlig, K. J., and Eckhardt, A.: Sicherheitsrelevante Barrieren bei der Endlagerung: Ungewissheiten aus der Perspektive der Ingenieurwissenschaften, TRANSENS-Bericht, https://www.transens.de, 2021. 